\title{
Research on Problems in the Reform of College Financial Management
}

\author{
DU Guoliang ${ }^{1, a}$, XIA Jing ${ }^{1, b_{*}}$ \\ ${ }^{1}$ Finance Department, Wuhan University of Textile, \\ Wuhan, P.R. China, 430200 \\ a e-mail: 95255286@qq.com, be-mail: callidora2015@163.com \\ *Corresponding author
}

Key words: Colleges and universities, Financial management, Reform

\begin{abstract}
Over the years, with the change of college financial management environment and the reform of it, some problems urgent to be solved come into being. Thus, this paper is aimed to internally and externally analyze theses problems and try to find out some optional measures. Considering the importance and urgency of personnel training and college construction, the author here proposes four measures: controlling the financial management at macro level and attaching importance to budget preparation; establishing long-term cooperation mechanism with financing institutions; improving the socialization of logistics; carrying on the personnel training and information reform. The author hopes that these problem analysis and optional measures might provide some ideas for other relevant studies.
\end{abstract}

\section{Introduction}

Economic development is closely linked with senior intellectuals training and college construction which are both based on the financial management. [1] An advanced and efficient system of financial management can contribute a lot to the healthy development of colleges, which consequently creates a virtuous cycle. In recent years, with the rapid development of economy, the government adjusts its funds allocation better for colleges and reforms them from many aspects, even covering some specific parts like budgeting preparation and personnel training, in accordance with market patterns. However, remarkable as the development is, there are still some problems urgent to be solved. Thus, the author here is intended to analyze some major problems and try to put forward some solutions.

\section{Problems of the Change of Financial Management Environment}

Due to the change of financial management environment, there are some new problems.

Firstly, financial management in colleges has not complied with the state fiscal policy tilts. In recent years, project funds from the government are fiscally cut down. But if considering the rapid economic growth, the economic base actually didn't decline a lot in the amount except some tilts in the funds allocation. However, contrasting with the stability of funds from the government, the scientific research funds and project funds are increasingly rising. [2] This striving contrast between them causes some problems in funds allocation and financial management. In this case, some colleges is unable to in line with the fiscal change. As a result, their financial management is obsessed by a lot of problems and eventually hinders the development of scientific research.

Secondly, the diversification of financing channels leads to the lag of financial management. It is well known that colleges were mainly supported by the funds from government and to some extent supplemented by the funds raised by themselves over the years. However, in recent years, with the rapid development of financial industry, bank loans have become their new financing channels. Obviously, it has solved the financing problems to certain extent. But we can't ignore the consequent problems they have brought. [3] On one hand, college managers have to rack their 
brains to find out the solution how to pay back the increasingly raised debt and how to enhance the business transactions between banks and colleges. On the other hand, they are also challenged to keep on their financial management timely.

Thirdly, college financial management in the information age urgently needs improvement. With the rapid development of internet and the broad application of information technology, firms of any meaningful size spare no efforts to meet the needs of market at home and abroad and qualify their hardware inside the system financial management by applying the most update financial software to this system and equipping [4] it with professional technicians. It should be the same with financial management in colleges. However, taking a look at most colleges now, we are surprised to find out that they didn't quite follow this tendency. Through some research, we draw the conclusion that it is the lack of technical support, insufficiency of funds high cost of financial software and external effect that lead to their unwillingness and inability to invest talents and materials to improve it. Thus, financial management should accordingly make the most of internet and information technology hoping to improve its efficiency.

\section{Measures and Problems of Financial Management Reform}

As for the financial management reform, it is obviously that both the government and colleges have actively taken measures which have promoting the reform a lot. However, there are still some emerging problems mainly in three parts.

A. Reform of Budgeting Preparation

In the current budgeting reforms, the financial management of colleges strictly follows the state financial management, namely the implementation of department budget, separation of revenue and expenditure, centralized payment for state finance and government procurement. As the public institution, all colleges and universities can realize the financial management on their own by cooperating with state budget. The college funds and fees which belong to the institutional revenues and expenses are the extra budgetary fund which shall be strictly regulated in accordance with the budget law. Specifically, the department budget transformed the traditional budgeting methods into the zero-base budget (ZBB). [5] As the extra budgetary funds, college funds shall also be strictly divided into two parts -- revenue and expenditure. That means, revenue and expenditure will have no influence on each other and have their own details for inspection. In addition, some colleges implement the centralized payment of state finance and government procurement system, which from the source ensures a sound college financial management from the source.

However, it also brings a series of problems. What comes first is the department budget. It mainly shows two remarkable problems resulting from the "zero-based budgeting" in practical work. First, staff numbers are generally based on the number of the previous year, thus the timeliness is relatively weak. Coupled with the existence of information asymmetry between government departments and universities, it is more prone to lead to the government cannot effectively monitor the financial management of universities. Second, the funds of colleges and universities are determined by the ratio of enrollment, so it is prone to make universities to blindly increase the number of enrollments. Currently, Chinese colleges and universities are distributed everywhere, but the nurturing of elite talents are relatively inadequate. This may not deny the reason from the unplanned increasing of enrollment number and paying little attention to its quality. In addition, the budgeting time and terms are also problematic in that it is likely to go to two extremes-- accounting the budget repeatedly or failing to reflect the educational expenditure.

B. Reform of Logistics Management

In recent years, colleges and universities' logistics have realized their socialization. Except for 
the basic canteens enjoying the state financial subsidies, part of colleges and universities' logistics are outsourced to enterprises. It is a necessary measure taken to cultivate the sense of competition and to enhance the service levels of colleges. With regards to the financial management of logistics in colleges, logistics socialization constantly improves the traditional management model in order to adapt to new demands. [6] In accounting, new accounting methods are constantly introduced, forming an important part of university financial management, which can eventually contribute to the preservation of state assets and avoidance of fraud loss phenomenon.

However, in practice, there are some unavoidable problems. On one hand, the logistics financial management cannot completely follow the colleges and universities' financial management so that logistics cannot be well integrated into the colleges and universities' financial management system. On the other hand, after the socialization of colleges and universities' logistics, it is difficult to coordinate between Logistics Group for profit and the nature of public institutions of colleges and universities. Financial management system in colleges and universities need to balance both of them and the related regulations are not comprehensive.

C. Reform of Financial Personnel

Equipping the staff with more professional knowledge by training is very necessary and important. As the financial management in colleges is a branch of the major financial management, the staffs are required to own high quality. Currently, most universities can choose people who have experience in financial management and provide specific training on how to use the hardware equipment. However, some problems still exist. The first one is the staff's shortage of professional skills. It is well known that the position requires highly specialized financial knowledge, and is closely related to the construction of colleges and universities. Therefore, the overall level of the current staff cannot meet this requirement. Secondly, in terms of staff training, for the consideration of cost saving, colleges always prefer to employ the centralized way of short-term training which makes the staff trained cannot completely digested all the information. The training effect finally will be below our expectation. Accordingly, the reform of financial personnel training needs to be improved.

\section{Reform Directions of Financial Management in the Future}

Aimed to solve the problems above, the author here proposes four reform directions.

Firstly, macro-control and budgeting are good choices for colleges. That means they should grasp the big picture and then draw lessons from the traditional ideas and methods of financial management according to the current running situation of colleges. Besides, they are also considered to create multiple financing channels and establish a new system of financing management which is in line with those multiple channels. Apart from self-reflection, it is also a good choice to learn from successful enterprises. Specifically, college managers should develop the sense of time saving and risk management both of which play important roles in the system of financial management. With respect to the budgeting, colleges should allocate their funds rationally and fairly. To be specific, they should combine the state financial subsidies, self-raised funds and other financing channels and keep balance among them so that they can provide projects of promising potential and scientific research value with sufficient funds. After budgeting preparation, it will be the budget monitoring. College managers should keep an eye on big projects, specifically what funds are used for and how funds are allocated, to guarantee the efficiency and rationality of fund utilizing.

Secondly, colleges should establish long-term cooperation with financial institutions. In recent years, because of the increasing shortage of state funds allocation, colleges ought to raise funds 
themselves by virtue of financial institutions. But that doesn't mean they can raise money without any restricts. In order to control the increasingly higher debt, they are required to rationally estimate the proper amount of funds and then carefully plan the amount of bank loans and repayment deadline in advance. Detailed plans should be covered in the budget preparation. These all above on one hand can largely enhance the long-term cooperation with financial institutions which finally contribute to the monitoring of fund flows. [7] On the other hand, they can ensure accurate communication between colleges and financial institutions which conduces to the symmetry of information in the system of financial management. However, the cooperation can not remain stable and healthy until colleges carefully estimate the financing risk and profit of projects under the consideration of their limited repayment capacity. At the same time, the mortgage of project assets can not influence other key financial indicators. That means, though there are problems in one project, other projects will still keep on their operation.

Thirdly, the pattern of logistic socialization should be improved. Apart from funds collection from financing institutions, the socialization of logistics is another important channel. It is known that logistics are characterized by their stable income of which college can make the most to enable the sufficient utilization of resources by means of issuing bonds to the staff. To some extent, it is a win-win way for both logistics and colleges. To issue bonds, colleges should take the interest rate and interests' allocation into consideration. As for the interest rate, it can be higher than that of state bonds since college bonds are much more stable and secured than state bonds. Then, it will stimulate the purchasing desire of the staff which can consequently pay the interests on loans as well as reduce financing cost. In terms of interest allocation, the staff can share the dividends through the bonds. That means, interests of the staff are closely linked with that of college. Thus, all the staff will devote more passion and motivation to their work hoping to enjoy long-term interests.

Fourthly, personnel training and information reform are also important. In order to deal with the problems above about personnel training, college can arm the staff with more knowledge about finance by employing its own teachers. It is the best and most economical way because it on one hand reduces the cost of teacher employment and on the other hand establishes long-term teaching mechanism which will enhance the overall quality of accountant. Besides, colleges are considered to apply information technology into personnel training. Nowadays, ad the system of financial management in firms is always equipped with advanced financial software, colleges can learn from it. They can generalize the common problems in financial management, employ professional groups to deal with them and develop system software together with other colleges and universities. Therefore, it not only forms the scale effect, especially increases mutual understanding and improvement through more communication, but also largely reduces the research cost.

\section{Conclusions}

Over the years, tough change and reform of college financial management environment have improves it a lot, there are still some problems urgent to be solved. The author internally and externally analyzes theses problems and finds out four optional measures: controlling the financial management at macro level and attaching importance to budget preparation; establishing long-term cooperation mechanism with financing institutions; improving the socialization of logistics; carrying on the personnel training and information reform. The author hopes that these problem analysis and optional measures might provide some ideas for other relevant studies. 


\section{References}

[1] Lin Justin Yifu,Guofu Tan.Policy Burdens, Accountability, and the Soft Budget Constraint. The American Economist. 1999

[2] Harvey S.Rosen.Public Finance. . 2005

[3] Becker W E.Paying the Piper:Productivity,Incentives,and Financingin U.S.Higher Education. Economics of Education Review. 2006

[4] Strauss,R.School Finance Reform:Moving from the School PropertyTax to Income Tax. Carnegie-Mellon University working paper. 2000

[5] Modigliani F,Miller M H,The Cost of Capital.Corporation Finance and the Theory of Investment. The American Economic Review . 1958

[6] Christopher D Ittner,David F Larcker. Assessing empirical research in managerial accounting: a value-based management perspective[J]. Journal of Accounting and Economics . 2001 (1)

[7] Bo-Goran Ekholm,Jan Wallin. Is the annual budget really dead?[J]. European Accounting Review . 2000 (4) 